\title{
SYN THESIS OF HETEROCYCLIC THIOAMIDES AND COPPER(II) COORDINATION COMPOUNDS BASED ON THEM
}

\author{
Anatoliy Ranskiy ${ }^{1, *}$, Natalia Didenko ${ }^{1}$, Olga Gordienko $^{1}$
}

DOI: dx.doi.org/10.23939/chcht11.01.011

\begin{abstract}
Arylamides of hetaryl-2-thiocarboxylic acid were synthesized via Willgerodt-Kindler modified reaction. The final products were studied by means of chemical analysis, IR- and ${ }^{1} \mathrm{H}$ NMR-spectroscopy. The coordination compounds of the general formula $\left[\mathrm{Cu}\left(\mathrm{HL}^{4}\right) \mathrm{Cl}_{2}\right]_{2}$. $\cdot x \mathrm{CH}_{3} \mathrm{OH}(x=0,2)$ were obtained via traditional and direct synthesis based on benzimidazol-2-N-(4-ethoxyphenyl) carbothioamide $\left(\mathrm{HL}^{4}\right)$. Using X-ray analysis the molecular and crystal structures of $\left[\mathrm{Cu}\left(\mathrm{HL}^{4}\right) \mathrm{Cl}_{2}\right]_{2} \cdot 2 \mathrm{CH}_{3} \mathrm{OH}$ complex were determined.
\end{abstract}

Keywords: heterocyclic thioamide, copper(II) binuclear complex, X-ray analysis.

\section{Introduction}

The modern development of coordination chemistry of $3 d$-metals and N,S-containing organic ligands is mainly connected with the synthesis of compounds with new biological [1], catalytic [2] and physico-mechanical [3] properties. The synthesis of heterocyclic thioamides with benzothiazole and benzimidazole fragments is complicated and connected with investigations of Willgerodt-Kindler modified reaction [4]. It is the reason for searching new methods of thioamides synthesis, their effective using in the coordination chemistry of $3 d$-metals [5] and obtaining compounds with a set of new chemical and physical properties. Previously the heterocyclic thioamides were obtained via thermal [6] or catalytic [3, 4] activation of elemental sulfur according to Eq. (1):

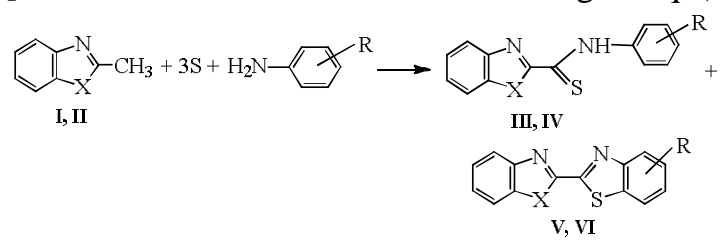

R = Alk, OAlk, Hal; X=S, I, III, V; X=NH, II, IV, VI

\footnotetext{
1 Vinnytsa National Technical University 95, Khmelnytske Ave., 21021 Vinnytsa, Ukraine

*ranskiy@gmail.com

(c) Ranskiy A., Didenko N., Gordienko O., 2017
}

The by-products of oxidative cyclization $\mathbf{V}$ and $\mathbf{V I}$ are formed additionally to the main arylamides of hetaryl2-thiocarbonic acid III and IV. In case of catalytic reaction, the sulfur-containing nucleophilic catalyst $\left(\mathrm{Na}_{2} \mathrm{~S} \cdot 9 \mathrm{H}_{2} \mathrm{O}\right)$ is used. The catalyst decomposes the initial cyclooctasulfan $\mathrm{S}_{8}$ to the reactive nucleophilic ions $\mathrm{HS}^{-}$ and $\mathrm{HS}_{8-x} \mathrm{~S}^{-}$[4]:

$$
\begin{gathered}
\mathrm{Na}_{2} \mathrm{~S}+\mathrm{H}_{2} \mathrm{O} \rightleftharpoons \mathrm{NaHS}+\mathrm{NaOH} \\
\mathrm{NaHS} \rightleftharpoons \mathrm{Na}^{+}+\mathrm{HS}^{-} \\
\mathrm{S}_{8}+\mathrm{HS}^{-} \rightleftharpoons \mathrm{HS}_{8-x} \mathrm{~S}^{-}+\mathrm{S}_{x}, \quad x=2-7
\end{gathered}
$$

The oxidation of active methyl group of the initial compounds I and II by sulfur (intermediate VII) is accompanied by formation of Schiff bases (intermediate VIII) and final compounds III and IV.

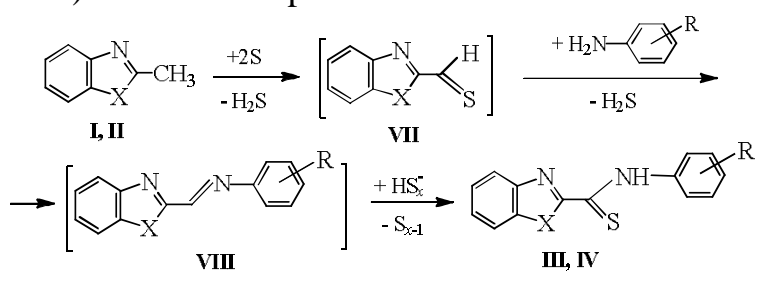

It should be noted that using the catalyst the yield of heterocyclic thioamides is increased by $2.0-2.5$ times $[3,4]$ compared with the reaction thermal activation (Eq. (1)). However, in this work we propose to improve the synthesis of heterocyclic thioamides by adding dimethylsulfoxide (DMSO) that increases their yield and decreases the reaction temperature. The synthesized thioamides were analyzed as bidentate ligands while complex formation with some $3 d$-metals.

It should be also noted that nowadays the direct synthesis of coordination compounds of transition $3 \mathrm{~d}-$ metals and thioamide ligands using $\mathrm{HL}-\mathrm{ROH}-\mathrm{HCl}-\mathrm{O}_{2}$ proton-donor systems is practically unstudied [7]. Meanwhile, such coordination compounds are widely used in engineering as additives to hydrocarbon materials [8] and model objects of copper(II) [8] and cobalt(II, III) [9] biologically active complexes. In addition, just theoretical studies of the mechanism of the redox reactions occurred on the $\mathrm{M}^{0}-\mathrm{Ox}-\mathrm{HL}-\mathrm{Solv}$ interface [10], are of particular interest. 
So, the aim of this work is to investigate copper(0, II) complex formation with heterocyclic thioamides.

\section{Experimental}

\subsection{M aterials and M ethods}

To synthesize the heterocyclic thioamides IIIa-IIIi (Table 1) and IVa-IVg (Table 2) we used 2-methylbenzothiazole, 2-methylbenzimidazole and aromatic amines purchased by Aldrich and Merck. The compounds were of CP grade with the main component content of $99 \%$.

For the synthesis of $\left[\mathrm{Cu}\left(\mathrm{HL}^{4}\right) \mathrm{Cl}_{2}\right]_{2} \cdot 2 \mathrm{CH}_{3} \mathrm{OH}$ complex we used the copper powder with mass part of metal $\geq 99.5 \%$ and particles size of $8.0 \pm 1.1 \mu \mathrm{m}$ (75 vol \%), determined by Saishin SKC-2000S microsedimentometer (Japan). Inorganic salts $\mathrm{CuCl}_{2} \cdot 2 \mathrm{H}_{2} \mathrm{O}$ and $\mathrm{Na}_{2} \mathrm{~S} \cdot 9 \mathrm{H}_{2} \mathrm{O}$ were of $\mathrm{CP}$ grade. Organic solvents $\left(i-\mathrm{C}_{3} \mathrm{H}_{7} \mathrm{OH}, \mathrm{CH}_{3} \mathrm{OH}\right.$ and DMSO $)$ were purchased by Merck and Aldrich and used as received without additional purification. Copper(II) content in the synthesized complex $\left[\mathrm{Cu}\left(\mathrm{HL}^{4}\right) \mathrm{Cl}_{2}\right]_{2} \cdot x \mathrm{CH}_{3} \mathrm{OH}(x=0,2)$ was determined by atomic-absorption spectroscopy using S-115 PKRS spectrometer. The elemental analysis for nitrogen content was carried out by Kjeldahl method, sulfur content - by Sheniger method [11].

IR-spectra of IIIa-IIIi, IVa-IVg compounds and $\left[\mathrm{Cu}\left(\mathrm{HL}^{4}\right) \mathrm{Cl}_{2}\right]_{2} \cdot x \mathrm{CH}_{3} \mathrm{OH}(x=0,2)$ complex were recorded within $4000-400 \mathrm{~cm}^{-1}$ using Specord 75 IR instrument. The samples were prepared as the tablets with $\mathrm{KBr}$. ${ }^{1}$ H NMR spectra were recorded using Varian VXR-200 $(200 \mathrm{MHz})$ and Varian VXR-300 (300 MHz) microwave spectrometers for DMSO- $\mathrm{d}_{6}$ solutions with tetramethylsilane as an internal standard.

X-ray analysis of monocrystal IX was carried out at $293 \mathrm{~K}$ using Siemens P3/PC diffractometer $\left(\mathrm{MoK}_{\alpha^{-}}\right.$ radiation, graphite monochromator, scanning method $\theta / 2 \theta$ ). The whole number of images are 3757 , including 3401 independent ones, $R_{\text {int }}=0.0740$. Crystals are monoclinic, $\quad \mathrm{P} 2_{1 / \mathrm{n}} ; \quad a=8.2001(3) \AA, \quad b=20.8052(5) \AA$, $c=11.3421(4) \AA ; \quad \beta=95.76(3)^{\circ}, \quad V=1925.31(10) \AA^{3}$, $Z=2$. For $\mathrm{C}_{32} \mathrm{H}_{30} \mathrm{Cl}_{4} \mathrm{~N}_{6} \mathrm{O}_{2} \mathrm{~S}_{2} \mathrm{Cu}_{2} \cdot 2 \mathrm{CH}_{3} \mathrm{OH} \quad M=$ $=927.74 \mathrm{~g} / \mathrm{mol}, \rho_{\text {calc. }}=1.600 \mathrm{~g} / \mathrm{cm}^{3}, \mu\left(\mathrm{M}_{0} \mathrm{~K} \alpha\right)=1.537 \mathrm{~mm}^{-1}$, $\mathrm{F}(000)=948$.

The components structure was decoded by the direct method and specified by the least-squares method relative to $F^{2}$ in full-matrix anisotropic approximation using SHELXTL programs [12]. Hydrogen atoms of methyl groups were assigned geometrically. Two solvated molecules of methyl alcohol are present in the crystal. Full-matrix anisotropic specification of non-hydrogen atoms is completed at $R=0.064$ according to 1918 images with $I \geq 2 \sigma(I) ; S=1.103$.

\subsection{Synthesis of Hetaryl-2- thiocarboxylic Acid Arylamides}

\subsubsection{Benzothiazol-2-N-(4- ethoxyphenyl)carbothioamide, IIIC}

The reactor equipped by a mechanical stirrer, thermometer and backflow condenser was loaded with $14.9 \mathrm{~g}(0.1 \mathrm{~mol})$ of 2-methylbenzthiazol, $13.7 \mathrm{~g}(0.1 \mathrm{~mol})$ of $p$-phenetidine, $9.6 \mathrm{~g}(0.3 \mathrm{~mol})$ of sulfur and $1.92 \mathrm{~g}$ ( $8 \mathrm{mmol}$ ) of $\mathrm{Na}_{2} \mathrm{~S} \cdot 9 \mathrm{H}_{2} \mathrm{O}$. The reaction mixture was stirred and $10 \mathrm{ml}$ of benzene was added. Azeotropic solution (benzene+water) was distilled at heating using Dean-Stark head. Then $5 \mathrm{ml}$ of DMSO were added, the temperature was increased to $423 \mathrm{~K}$ and the mixture was kept under the mentioned temperature till the end of hydrogen sulfide evolving. The reaction was controlled by the qualitative reaction of lead(II) cation. After the reaction mass was cooled till $333-338 \mathrm{~K}$ it was extracted by $5 \% \mathrm{NaOH}$ solution $(3 \times 150 \mathrm{ml})$. The alkaline extracts were collected and neutralized by diluted solution of hydrochloric acid. The precipitate was filtered, dried at the air and recrystallized from the aqueous solutions of methyl and isopropyl alcohols. The yield was $22.6 \mathrm{~g}$ (72.0\%); m.p. was 400-401 K.

Other arylamides (IIIa-IIIi) were synthesized in the same way. Their physico-chemical characteristics are given in Table 1.

\subsubsection{Benzimidazol-2-N-(4- bromphenyl)carbothioamide, IVe}

The reactor equipped by the mechanical stirrer, thermometer and backflow condenser was loaded with $26.4 \mathrm{~g} \quad(0.2 \mathrm{~mol}) \quad$ of 2-methylbenzimidazole, $\quad 36.1 \mathrm{~g}$ $(0.21 \mathrm{~mol})$ of $p$-bromaniline, $19.2 \mathrm{~g}(0.6 \mathrm{~mol})$ of sulfur, $3.6 \mathrm{~g}(15 \mathrm{mmol})$ of $\mathrm{Na}_{2} \mathrm{~S} \cdot 9 \mathrm{H}_{2} \mathrm{O}$ and $30 \mathrm{ml}$ of DMSO. The reaction mixture was heated at $383-393 \mathrm{~K}$ for $1.5 \mathrm{~h}$ without backflow condenser and then at $403-413 \mathrm{~K}$ for $10 \mathrm{~h}$ with it. The mixture was cooled to $343-353 \mathrm{~K}$ and extracted by $5 \% \mathrm{NaOH}(3 \times 250 \mathrm{ml})$. The alkaline extracts were collected. The hot solution was filtrated, cooled to the ambient temperature and acidified by diluted sulfuric acid till $\mathrm{pH}$ became $5-6$. The yellow precipitate was filtered, dried at the air and recrystallized from the aqueous solution of isopropyl alcohol. Then it was reprecipitated from the diluted $\mathrm{NaOH}$ solution and again recrystallized from the aqueous solution of $\mathrm{CH}_{3} \mathrm{OH}$. The yield was $46.8 \mathrm{~g}(70.5 \%)$; m.p. was $432.5-433 \mathrm{~K}$. 
Other arylamides (IVa-IVg) were synthesized in the same way. Their physico-chemical characteristics are given in Table 2.

\subsection{Synthesis \\ of $\left[\mathrm{Cu}\left(\mathrm{HL}^{4}\right) \mathrm{Cl}_{2}\right]_{2} \cdot{ }_{x} \mathrm{CH}_{3} \mathrm{OH}(x=0,2)$ Coordination Compounds}

\subsubsection{Di( $\mu$-chloro)-dichloro-bis[benzimidazol-2-N - (4-ethoxyphenyl)carbothioamide]copper(II) solvated by methanol, IX. Method A.}

$4.46 \mathrm{~g}(15.0 \mathrm{mmol})$ of benzimidazol-2-N-(4ethoxyphenyl) carbothioamide were dissolved in $200 \mathrm{ml}$ of hot unhydrous methyl alcohol. The solution was acidified by $9 \mathrm{ml}(90.0 \mathrm{mmol})$ of $30 \% \mathrm{HCl}$ and then $0.95 \mathrm{~g}$ (15.0 mmol) of copper powder was added under stirring. The obtained mixture was quickly cooled to $293 \mathrm{~K}$ and intensively stirred for $11 \mathrm{~h}$. The precipitate of violetbrown color was filtrated using Schott filter, washed by unhydrous methanol $(3 \times 10 \mathrm{ml})$ and dried in desiccator over $\mathrm{CaCl}_{2}$. The yield was $5.96 \mathrm{~g}(92 \%)$; melting point 473-480 K (with decomp.). Found, \%: N 5.98; S 6.57; $\mathrm{Cu}$ 13.54. For $\left[\mathrm{Cu}_{2}\left(\mathrm{C}_{32} \mathrm{H}_{30} \mathrm{~N}_{6} \mathrm{O}_{2} \mathrm{~S}_{2}\right) \mathrm{Cl}_{4}\right] \cdot 2 \mathrm{CH}_{3} \mathrm{OH}$ calculated, \%: N 6.04; S 6.91; $\mathrm{Cu} 13.70$.

\subsection{2. $\mathrm{Di}(\mu$-chloro)-dichloro-bis[benzimidazol-2-N - (4-ethoxyphenyl)carbothioamide]copper(II), $X$. Method B.}

$2.59 \mathrm{~g}(15.2 \mathrm{mmol})$ of $\mathrm{CuCl}_{2} \cdot 2 \mathrm{H}_{2} \mathrm{O}$ dissolved in $45 \mathrm{ml}$ of hot unhydrous methyl alcohol and $4.0 \mathrm{ml}$ $(40.0 \mathrm{mmol})$ of $30 \% \mathrm{HCl}$ were added to $4.46 \mathrm{~g}$ (15.0 mmol) of benzimidazol-2-N-(4-ethoxyphenyl) carbothioamide dissolved in $100 \mathrm{ml}$ of hot unhydrous methyl alcohol under constant stirring. The solution was stirred at 318-323 K for $30 \mathrm{~min}$. The formed precipitate of violet-brown color was filtrated using Schott filter, washed by unhydrous methanol $(3 \times 25 \mathrm{ml})$ and dried in desiccator at $363-373 \mathrm{~K}$ till the weight became constant. The yield was $6.15 \mathrm{~g}(95 \%)$; melting point $473-480 \mathrm{~K}$ (with decomp.). Found, \%: N 9.41; S 7.36; Cu 14.45. For $\left[\mathrm{Cu}_{2}\left(\mathrm{C}_{32} \mathrm{H}_{30} \mathrm{~N}_{6} \mathrm{O}_{2} \mathrm{~S}_{2}\right) \mathrm{Cl}_{4}\right] \cdot 2 \mathrm{CH}_{3} \mathrm{OH}$ calculated, \%: $\mathrm{N}$ 9.73; $\mathrm{S} 7.43 ; \mathrm{Cu} 14.72$.

\section{Results and Discussion}

\subsection{Synthesis of Heterocyclic Thioamides}

To continue the investigations of new heterocyclic thioamides synthesis via Willgerodt-Kindler modified reaction [3,4] we obtained IIIa-IIIi and IVa-IVg compounds by adding aprotic solvent DMSO to the reaction products:

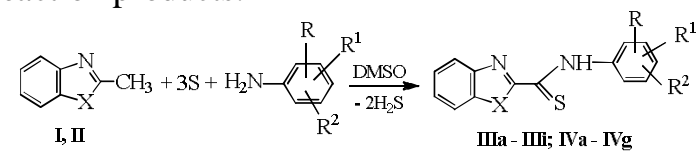

$\mathrm{X}=\mathrm{S} ; \mathrm{R}=\mathrm{R}^{1}=\mathrm{H}, \mathrm{R}^{2}=\mathrm{CH}_{3}-3$, IIIa $; \mathrm{R}=\mathrm{R}^{1}=\mathrm{H}$,

$\mathrm{R}^{2}=\mathrm{OCH}_{3}-2$, IIIb; $\mathrm{R}=\mathrm{R}^{1}=\mathrm{H}, \mathrm{R}^{2}=\mathrm{OC}_{2} \mathrm{H}_{5}-4$, IIIc; $\mathrm{R}=\mathrm{H}$,

$\mathrm{R}^{1}=\mathrm{CH}_{3}-2, \mathrm{R}^{2}=\mathrm{CH}_{3}-4$, IIId $; \mathrm{R}=\mathrm{H}, \mathrm{R}^{1}=\mathrm{CH}_{3}-2$,

$\mathrm{R}^{2}=\mathrm{CH}_{3}-5$, IIIe; $\mathrm{R}=\mathrm{CH}_{3}-2, \mathrm{R}^{1}=\mathrm{CH}_{3}-4, \mathrm{R}^{2}=\mathrm{CH}_{3}-6$,

IIIf; $\mathrm{R}=\mathrm{R}^{1}=\mathrm{H}, \mathrm{R}^{2}=\mathrm{Cl}-2$, IIIg; $\mathrm{R}=\mathrm{R}^{1}=\mathrm{H}, \mathrm{R}^{2}=\mathrm{Cl}-4$,

IIIh; $\mathrm{R}=\mathrm{R}^{1}=\mathrm{H}, \mathrm{R}^{2}=\mathrm{Br}-4$, IIII.

$\mathrm{X}=\mathrm{NH} ; \mathrm{R}=\mathrm{H}, \mathrm{R}^{1}=\mathrm{CH}_{3}-2$, IVa; $\mathrm{R}=\mathrm{H}, \mathrm{R}^{1}=\mathrm{OCH}_{3}-2$,

IVb; $\mathrm{R}=\mathrm{H}, \mathrm{R}^{1}=\mathrm{OC}_{2} \mathrm{H}_{5}-4, \mathbf{I V} \mathbf{2} ; \mathrm{R}=\mathrm{CH}_{3}-2, \mathrm{R}^{1}=\mathrm{CH}_{3}-4$,

IVd; $\mathrm{R}=\mathrm{H}, \mathrm{R}^{1}=\mathrm{Cl}-4$, IVe; $\mathrm{R}=\mathrm{H}, \mathrm{R}^{1}=\mathrm{Br}-4$, IVf; $\mathrm{R}=\mathrm{H}$,

$\mathrm{R}^{1}=\mathrm{F}-4, \mathbf{I V g}$

It was previously noted that $\mathrm{Na}_{2} \mathrm{~S} \cdot 9 \mathrm{H}_{2} \mathrm{O}$ nucleophilic catalyst activates $\mathrm{S}_{8}$ cyclooctasulfone and provides the formation of $\mathrm{HS}^{-}, \mathrm{HS}_{8-x} \mathrm{~S}^{-}$reactive nucleophilic ions and final heterocyclic thioamides III and IV (Eqs. (2)-(5)). The additional introduction of DMSO aprotic solvent increases thioamides yield by $15-27 \%$ due to the following possible reasons:

- the increase in $\mathrm{HS}_{8-x} \mathrm{~S}^{-}$ion nucleophilicity;

- the increase in the rate of 2-methylhetarenes methyl group thiolation reaction (formation of intermediate VII) and shift of thione-thiol equilibrium toward the final reaction products III and IV:

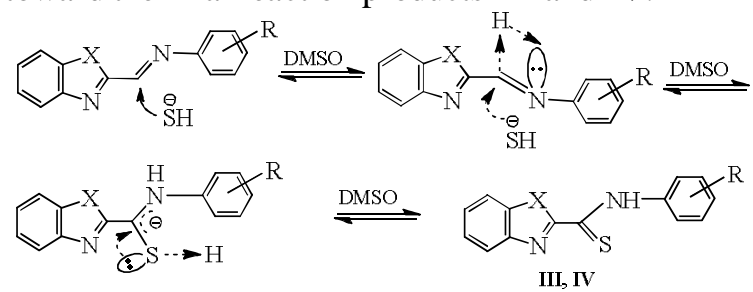

Physico-chemical properties of the synthesized heterocyclic thioamides are represented in Tables 1 and 2 . The composition and structure of all synthesized compounds were investigated by elemental analysis and ${ }^{1}$ H NMR spectroscopy. In addition, the structure of the compounds IVa-IVf was studied by IR-spectroscopy.

So, for the compounds IVa-IVf the most typical vibrations are stretching vibrations of $v(\mathrm{~N}-\mathrm{H})$ thioamide group of average or high intensity in the area of $3370-3260 \mathrm{~cm}^{-1}$, stretching vibrations of $\mathrm{v}(\mathrm{N}-\mathrm{H})$ of heterocyclic fragment of average intensity within $3095-3015 \mathrm{~cm}^{-1}$ and multiplex vibrations of thioamide group which were interpreted as vibrations of "B"-, " $D$ "and "E"-band [7]. The typical stretching vibrations of "B"-band $(\mathrm{C}=\mathrm{N}+\mathrm{N}-\mathrm{H})$ with greater contribution of $\mathrm{N}-\mathrm{H}$ group; " $\mathrm{D}$ "-band $(\mathrm{C}-\mathrm{N}+\mathrm{C}=\mathrm{S})$ with greater contribution of $\mathrm{C}-\mathrm{N}$ group and "E"-band $(\mathrm{C}=\mathrm{S}+\mathrm{C}-\mathrm{N})$ with greater contribution of $\mathrm{C}=\mathrm{S}$ group are represented in Table 3 . 
Anatoliy Ranskiy et al.

$\frac{1}{8}$

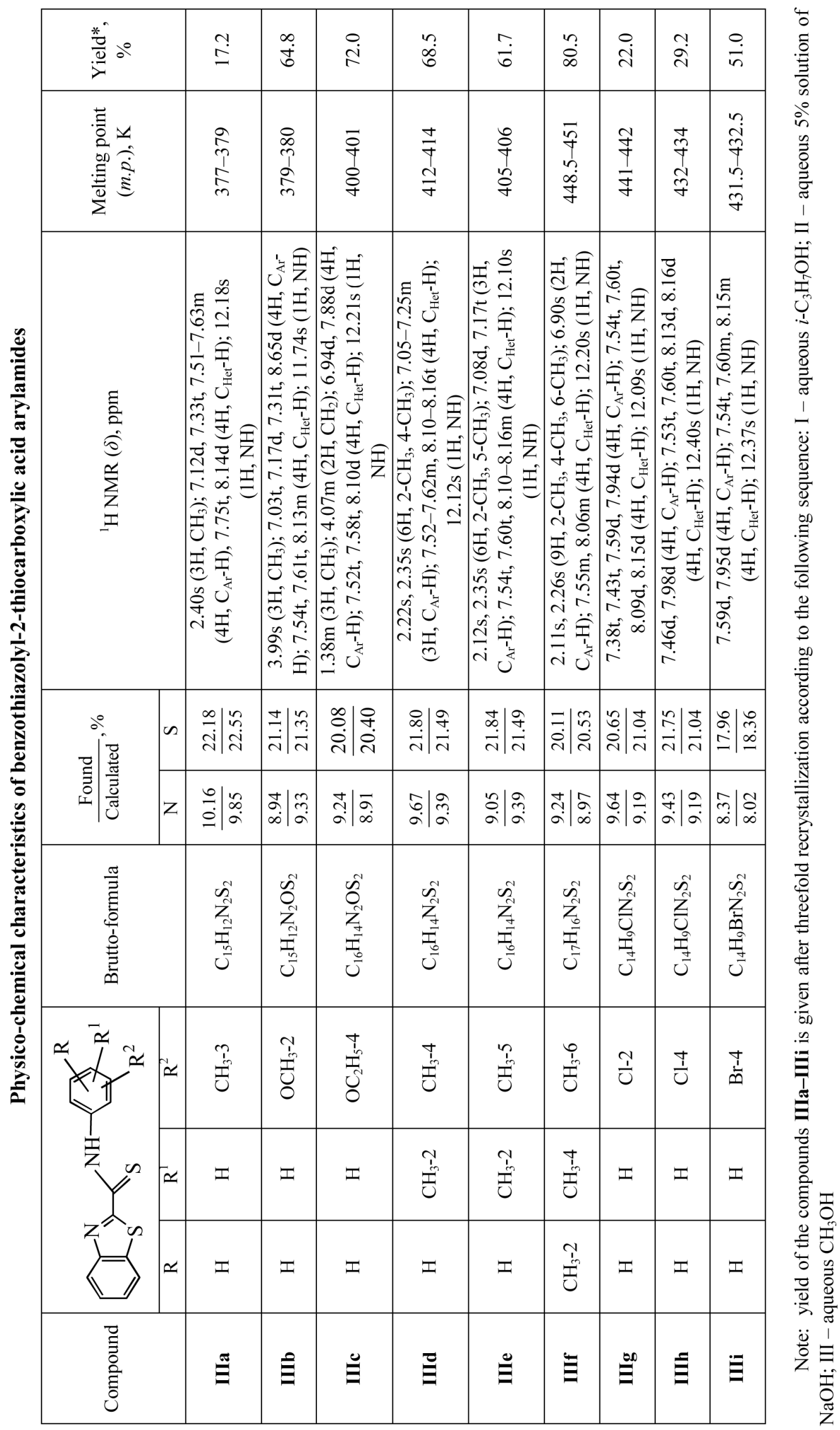


$\frac{2}{\frac{\pi}{3}}$

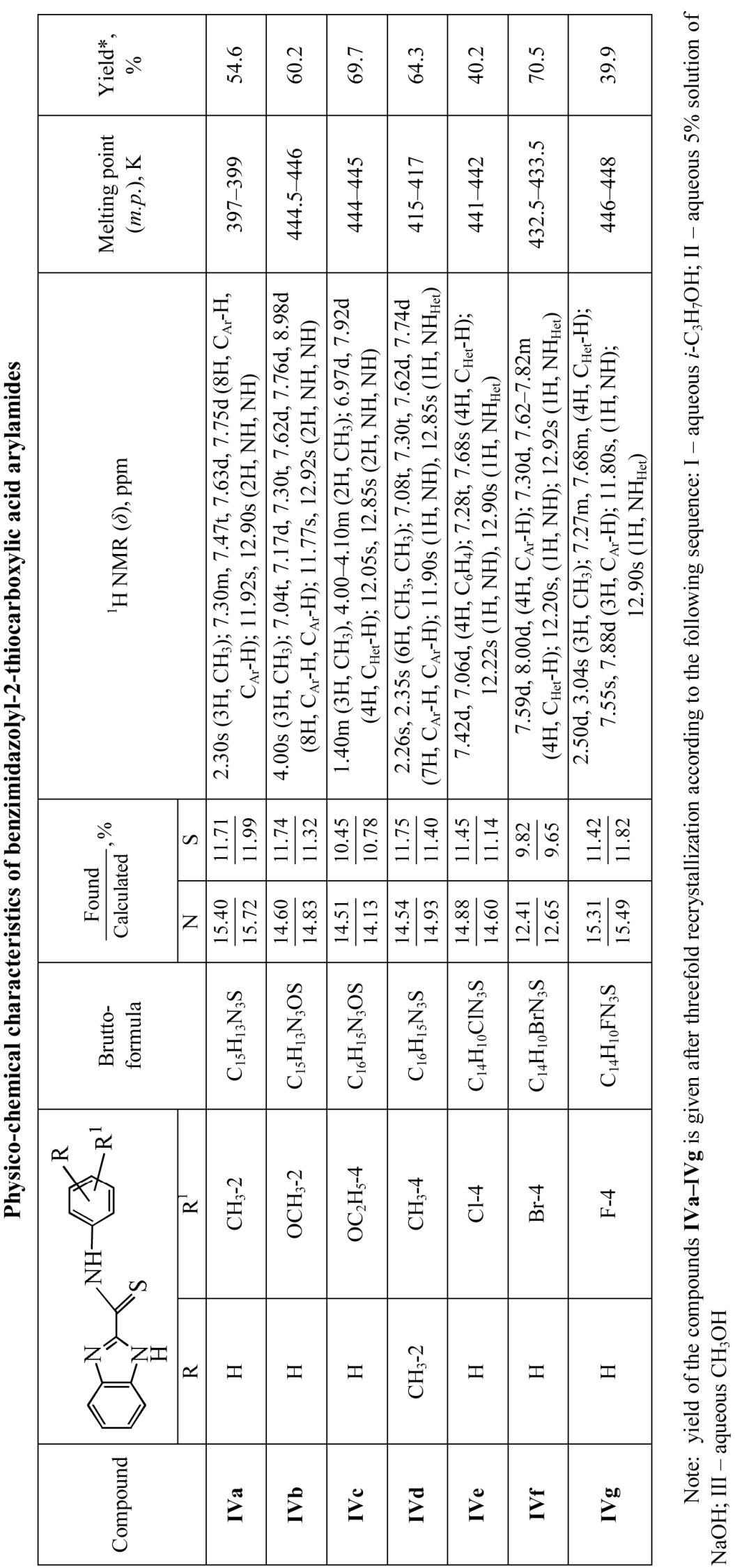




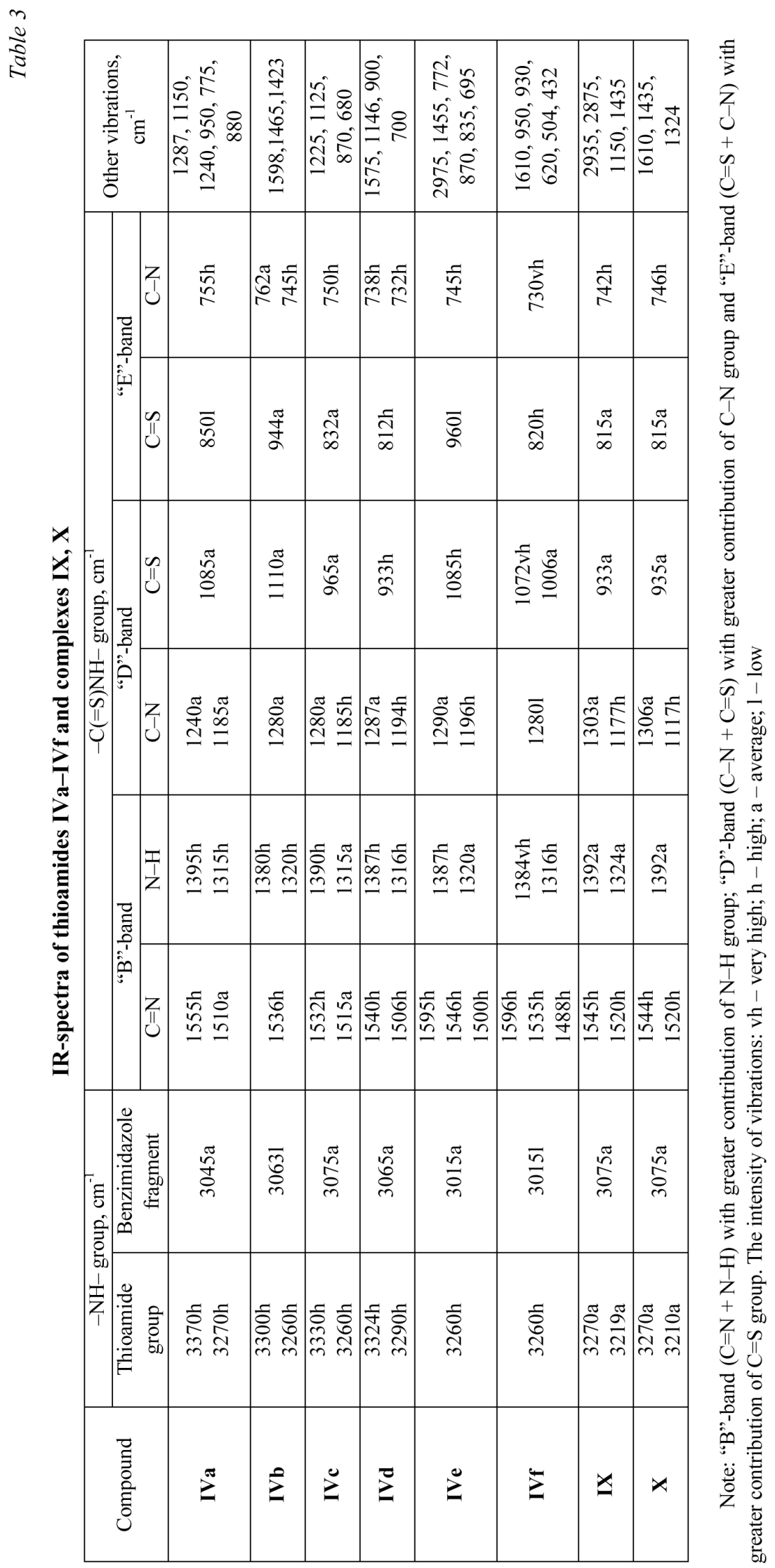


${ }^{1} \mathrm{H}$ NMR spectra of the compounds IIIa-IIII (Table 1) represent proton signals of aromatic nuclei, benzothiazole fragment and NH thioamide group. Proton signals of 1,4-disubstituted phenylene (compounds IIIc, IIIh and IIIi) usually appear as two doublets within $6.94-7.98 \mathrm{ppm}$ and signals of 1,2-substituted fragment (IIIb and IIIg) - as two doublets and two triplets within $7.03-8.65 \mathrm{ppm}$. Proton signals of methyl group in $\mathrm{N}$-tolylamide fragment (IIIa, IIId, IIIe and IIIf) appear as a singlet within 2.11-2.40 ppm. However, protons of the same groups in methoxyl fragment (IIIb, IIIc) appear as the singlet in a lower field (3.99 ppm), methyl group (IIIc) - in the area of $1.38 \mathrm{ppm}$ and methylene group - in the area of $4.07 \mathrm{ppm}$. Proton signals of benzothiazole fragment usually appear as two doublets $(8.06-8.16 \mathrm{ppm})$ and two triplets $(7.52-7.61 \mathrm{ppm})$. Protons of NH-group appear as the singlet within $12.10-12.40 \mathrm{ppm}$, except for IIIb, the proton of which gives signal at $11.74 \mathrm{ppm}$. Relation of proton signals of 1,4- and 1,2-disubstituted phenylene, methyl and methoxyl groups of the compounds IVa-IVg are similar to those of thioamides IIIa-IIIi (Table 2). ${ }^{1} \mathrm{H}$ NMR spectra of the compounds IVa-IVg differ by two $\mathrm{NH}$-groups in their structure: thioamide and benzimidazole fragments. Signals of NH proton of thioamide group (IVa-IVg) appear as the singlet within 11.77-12.22 ppm; protons of benzimidazole fragment - within 12.85-12.92 ppm.

\subsection{Synthesis of $\left[\mathrm{Cu}\left(\mathrm{HL}^{4}\right) \mathrm{Cl}_{2}\right]_{2} \cdot 2 \mathrm{CH}_{3} \mathrm{OH}$ Complex}

Earlier we assumed [7] that the coordination compounds obtained via the direct synthesis, have a dimeric structure. Their general formula is: $\left[\mathrm{Cu}\left(\mathrm{HL}^{1-3}\right) \mathrm{Cl}_{2}\right]_{2}$, where $\mathrm{HL}^{1}-\mathrm{C}_{7} \mathrm{H}_{5} \mathrm{~N}_{2} \mathrm{C}(=\mathrm{S}) \mathrm{NHC}_{6} \mathrm{H}_{5}, \quad \mathrm{HL}^{2}-$ $\mathrm{C}_{7} \mathrm{H}_{5} \mathrm{~N}_{2} \mathrm{C}(=\mathrm{S}) \mathrm{NHC}_{6} \mathrm{H}_{4} \mathrm{CH}_{4}-4$,

$\mathrm{HL}^{3} \quad-$ $\mathrm{C}_{7} \mathrm{H}_{5} \mathrm{~N}_{2} \mathrm{C}(=\mathrm{S}) \mathrm{NHC}_{6} \mathrm{H}_{4} \mathrm{Br}-4$. To confirm this assumption here we obtain metal-chelates $\mathbf{I X}$ and $\mathbf{X}$ via direct and traditional synthesis according to the following scheme:

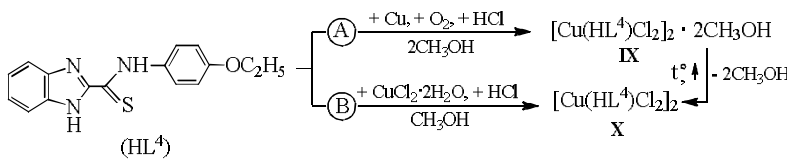

The same synthesis conditions for the compounds of the general formula $\left[\mathrm{Cu}\left(\mathrm{HL}^{1-3}\right) \mathrm{Cl}_{2}\right]_{2}$ [7] and complex IX confirm the identity of their compositions and presence of dimeric structure. $\mathrm{CH}_{3} \mathrm{OH}$ solvent and ligands of different nature (thioamide, $\mathrm{HCl}$ ) may be the potential donors of hydrogen cation. However, neither methyl alcohol (autoprotolysis: $\quad 2 \mathrm{CH}_{3} \mathrm{OH} \rightleftharpoons \mathrm{CH}_{3} \stackrel{\ominus}{\mathrm{O}}+\mathrm{CH}_{3} \stackrel{\oplus}{\oplus}_{2}$ ), nor thioamide ligand (dissociation of weak $\mathrm{NH}$ acid: $\mathrm{HL} \rightleftharpoons \stackrel{\oplus}{\mathrm{H}}+\stackrel{\oplus}{\mathrm{L}})$ are capable to compete with the dissociation of strong acid $\mathrm{HCl} \longrightarrow \stackrel{\oplus}{\mathrm{H}}+\stackrel{\ominus}{\mathrm{C}}$ and its further participation in formation of compound $\mathbf{I X}$ dimeric structure:

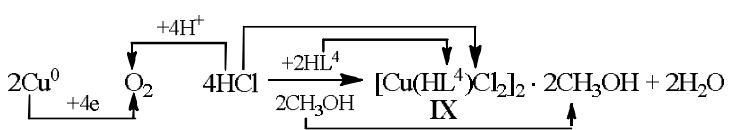

The composition of compounds IX and $\mathbf{X}$ was determined by elemental analysis, their structure - by IR-investigations (Table 3). The comparison of IVc and IX, X IR-spectra confirms the proceeding of complexation reaction and their structure (Scheme (8)).

IR-spectra of the compounds IX and $\mathbf{X}$ are practically identical. There is the shift of thioamide group $v(\mathrm{~N}-\mathrm{H})$ bond vibrations by $60 \mathrm{~cm}^{-1}$ compared with IVc whereas stretching vibrations of benzimidazole fragment $v(\mathrm{~N}-\mathrm{H})$ bond are the same. For $\mathrm{v}(\mathrm{N}-\mathrm{H})$ bonds (band "B") the strong stretching vibrations are typical, as well as their shift toward the high field by 13 and $9 \mathrm{~cm}^{-1}$ for the compounds IX and $\mathbf{X}$, respectively. Stretching vibrations of $v(\mathrm{C}-\mathrm{H})$ and $\mathrm{v}(\mathrm{C}=\mathrm{S})$ bonds (band "D") of the average intensity shift toward high and low fields by 23 and $29 \mathrm{~cm}^{-1}$, respectively. For the band " $\mathrm{E}$ " the shift of $\mathrm{v}(\mathrm{C}=\mathrm{S})$ stretching vibrations toward low field by $17 \mathrm{~cm}^{-1}$ is typical. The spectral data are confirmed by the results of other investigations [7] and prove the structure of the compounds IX and $\mathbf{X}$ obtained via both direct and traditional synthesis.

\section{3. $\mathrm{X}$-ray Analysis of $\left[\mathrm{Cu}_{2}\left(\mathrm{C}_{32} \mathrm{H}_{30} \mathrm{~N}_{6} \mathrm{O}_{2} \mathrm{~S}_{2}\right) \mathrm{Cl}_{4}\right] \cdot 2 \mathrm{CH}_{3} \mathrm{OH}, \mathrm{IX}$}

The general view of the molecule, bonds length and valence angles of the compound IX are represented in Fig. 1.

Crystal structure of the compound IX is a copper(II) bicyclic complex of $\mathrm{Cu}_{2}(\mathrm{HL})_{2} \mathrm{Cl}_{4}$ $\left(\mathrm{HL}=\mathrm{C}_{16} \mathrm{H}_{15} \mathrm{~N}_{3} \mathrm{OS}\right)$ with methyl alcohol (1:2). Binuclear complex has two structurally equivalent copper atoms located at the distance of $3.620 \AA$ between each other. Every copper atom is five-coordinated by three atoms of chlorine, two of which are bridge ones, and atoms of nitrogen and sulfur of $\left(\mathrm{HL}^{4}\right)$ thioamide ligand. The coordination polyhedron is a strongly deformated bipyramide, where $\mathrm{N}(1)$ and $\mathrm{Cl}(2 \mathrm{~A})$ atoms are in the axial position and $\mathrm{S}(1), \mathrm{Cl}(1)$ i $\mathrm{Cl}(2)$ - in the equatorial one (valence angles $\mathrm{N}(1)-\mathrm{Cu}(1)-\mathrm{Cl}(2 \mathrm{~A}) \quad 170.4(1)^{\circ} ; \mathrm{S}(1)-$ $\mathrm{Cu}(1)-\mathrm{Cl}(1) 131.54(8)^{\circ} ; \mathrm{S}(1)-\mathrm{Cu}(1)-\mathrm{Cl}(2) 117.12(7)^{\circ}$ and $\left.\mathrm{Cl}(1)-\mathrm{Cu}(1)-\mathrm{Cl}(2) 117.12(7)^{\circ}\right)$. The atom of $\mathrm{Cu}(1)$ is actually in the plane of equatorial atoms (deviation is $0.028(1) \AA$ ).According to X-ray analysis (Fig. 1) there are three planar fragments in the molecule of thioamide ligand: benzimidazole bicycle (fragment $A$, mean square deviation of atoms from the plane is $0.013 \AA)$; $\mathrm{S}(1), \mathrm{N}(3)$, $\mathrm{C}(8)$ and $\mathrm{C}(9)$ atoms, (fragment $B$, deviation is $0.011 \AA$ ) and ethoxyphenyl radical (fragment $C$, deviation is $0.036 \AA$ ). The rotation angles of fragments $B$ and $C$ relative to $A$ are 16.8 and $111.6^{\circ}$, respectively. 


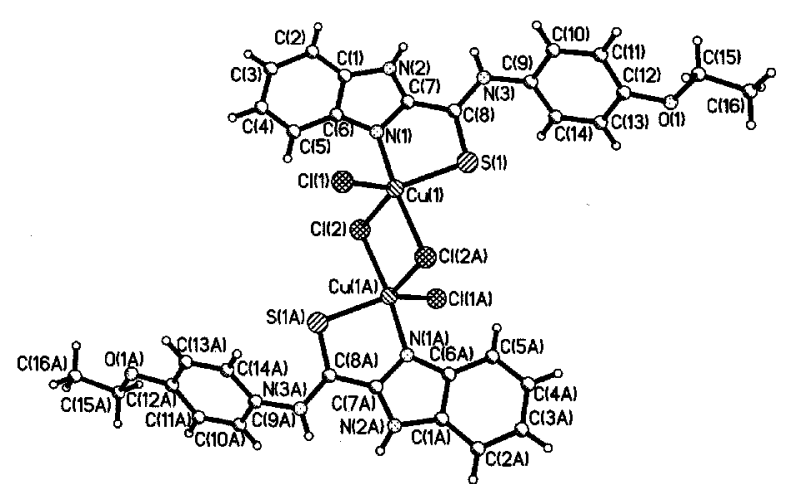

Methyl alcohol molecules occupy the position in external sphere and are bounded by hydrogen bonds between each other and nitrogen and oxygen atoms of $\mathrm{N}(3)-\mathrm{H}(3 \mathrm{~N}) \cdots \mathrm{O}(1 \mathrm{~S})$ thioamide ligand $(\mathrm{H} \cdots \mathrm{O} \quad 1.97 \AA$, $\left.\mathrm{N}-\mathrm{H} \cdots \mathrm{O} 153^{\circ}\right)$.

The length of $\mathrm{N}(1)-\mathrm{C}(7)$ bond in benzimidazole fragment is 1.341(7) $\AA$, that approximates to the mean value of carbon-nitrogen double bond (1.339 $\AA$ ) [13]. At the same time $\mathrm{C}(8)-\mathrm{S}(1)$ bond is shorter than typical values of $\mathrm{C}=\mathrm{S}$ double bond (cf. 1.632(6) and $1.671 \AA$ ). The length of other bonds is typical [14].

\section{Conclusions}

New arylamides of hetaryl-2-thiocarboxylic acid were synthesized via Willgerodt-Kindler modified reaction. The introduction of DMSO aprotic solvent into the reaction mass increases the yield of heterocyclic thioamides by $15-27 \%$. The composition and structure of the final products were studied by means of chemical analysis, IR- and ${ }^{1} \mathrm{H}$ NMR-spectroscopy.

We synthesized di( $\mu$-chloro)-dichloro-bis[benzimidazol-2-N-(4-ethoxyphenyl)carbothioamide]copper(II) coordination compound solvated by methanol. Its composition and binuclear structure were studied using IR-spectroscopy and X-ray analysis.

$\mathrm{X}$-ray analysis was used to examine the dimeric structure of the complex compounds of general formula $\left[\mathrm{Cu}\left(\mathrm{HL}^{1-4}\right) \mathrm{Cl}_{2}\right]_{2} \cdot x \mathrm{CH}_{3} \mathrm{OH}(x=0,2)$. It was determined that crystals are monoclinic: $a=8.2001(3) \AA$, $b=20.8052(5) \AA, c=11.3421(4) \AA$, spatial group $\mathrm{P} 2_{1 / n}$, $Z=2$. Copper(II) binuclear coordination compound has four chloride anions, two of which are bridge ones, two neutral molecules of benzimidazol-2-N-(4-ethyxyphenyl)carbthioamide (HL), and two solvated molecules of methyl alcohol.

\section{References}

[1] Wang F., Langley R., Gulten G. et al.: J. Exp. Med., 2007, 204, 73. [2] Winogradova V. and Maizus Z.: Kinetika i Kataliz, 1971, 12, 1322.
Fig. 1. Molecular structure of the compound IX. The main bonds length $(\AA): \mathrm{Cu}(1)-\mathrm{Cl}(1) 2.313(2), \mathrm{Cu}(1)-\mathrm{Cl}(2)$ 2.563(2),

$\mathrm{Cu}(1)-\mathrm{Cl}(2 \mathrm{~A})$ 2.271(2), $\mathrm{Cu}(1)-\mathrm{S}(1)$ 2.293(2), $\mathrm{Cu}(1)-\mathrm{N}(1)$ 1.949(4), S(1)-C(8) 1.632(6), O(1)-C(12) 1.362(7), O(1)-C(15) 1.439(7), N(1)-C(7) 1.341(7),

$\mathrm{N}(1)-\mathrm{C}(6)$ 1.396(6). Valence angles: $\mathrm{N}(1) \mathrm{Cu}(1) \mathrm{Cl}(2 \mathrm{~A})$

170.4(1) $, \mathrm{N}(1) \mathrm{Cu}(1) \mathrm{S}(1) 84.8(1)^{\circ}, \mathrm{S}(1) \mathrm{Cu}(1) \mathrm{Cl}(2 \mathrm{~A})$

88.33(7) ${ }^{\circ}, \mathrm{N}(1) \mathrm{Cu}(1) \mathrm{Cl}(1) 94.1(1)^{\circ}, \mathrm{Cl}(1) \mathrm{Cu}(1) \mathrm{Cl}(2 \mathrm{~A})$

95.55(6) $)^{\circ}, \mathrm{S}(1) \mathrm{Cu}(1) \mathrm{Cl}(1) 131.54(8)^{\circ}, \mathrm{N}(1) \mathrm{Cu}(1) \mathrm{Cl}(2)$

89.3(1) ${ }^{\circ}, \mathrm{Cl}(2) \mathrm{Cu}(1) \mathrm{Cl}(2 \mathrm{~A}) 87.78(6)^{\circ}, \mathrm{S}(1) \mathrm{Cu}(1) \mathrm{Cl}(2)$

117.12(7) ${ }^{\circ}, \mathrm{Cl}(1) \mathrm{Cu}(1) \mathrm{Cl}(2) 111.29(6)^{\circ}, \mathrm{Cu}(1) \mathrm{Cl}(2) \mathrm{Cu}(1 \mathrm{~A})$ $92.22(6)^{\circ}$

[3] Ranskiy A., Boichenko S., Gordienko O. et al.: Composytsyini Mastylni Materialy na Osnovi Tioamidiv ta ich Complexnykh spoluk. Vinnytsa VNTU, Vinnytsa 2012.

[4] Ranskiy A. and Evseeva M.: Sintez, Budova i Reakcii Komplexoutvorennya Aromatychnykh i Heterocyclichnykh Tioamidiv. Vinnytsa VNTU, Vinnytsa 2009.

[5] Valdez-Rojas J. E., Roios-Guerra H., Ramirez-Sanchez A. et al.: Can. J. Chem., 2012, 90, 567.

[6] Koketsu M. and Ishihara H.: Curr. Org. Synth., 2007, 4, 15.

[7] Ranskiy A. and Didenko N. : Chem. Chem. Technol., 2014, 8, 317.

[8] Uraev A., Nivorozhkin A., Korshunov O. et al.: Coordinats. Khimia, 1999, 25, 79.

[9] Didenko N. and Ranskiy A.: Visnyk Vinnyts. Politechn. Inst., 2012, 3, 182.

[10] Egorov A., Matynhova S. and Anisimov A.: Appl. Organometall. Chem., 2005, 19, 605.

[11] Klimova V.: Osnovnye Micrometody Analiza Organicheskykh Soedineniy. Khimiya, Moskva 1975.

[12] Sheldrick G.: SHELXTL PLUS. PC Version. A system of computer programs for the determination of structure from X-ray diffraction data. Rev. 5.1, 1998.

[13] Burgi H. and Dunitz J.: Structure Correlation. VCH., Weinheim 1994.

[14] Orpen G., Brammer L., Allen F. H. et al.: J. Chem. Dalton Trans., 1989, 12, S1.

Received: September 16, 2015 / Revised: December 23, 2015 / Accepted: M ay 12, 2016

\section{СИНТЕЗ ГЕТЕРОЦИКЛІЧНИХ ТІОАМІДІВ ТА КООРДИНАЦИЙНИХ СПОЛУК КУПРУМУ(II) НА ÏХ ОСНОВI}

Анотація. Модифікованою реакиією ВільгеродтаКіндлера синтезовані ариламіди гетарил-2-тіокарбоновоі кислоти. Отримані сполуки досліджені методами хімічного аналізу, ІЧ- та ${ }^{1}$ Н ЯМР-спектроскопією. Методами традииійного та прямого синтезу на основі бензімідазол-2- $N-(4-$ етоксифенил)карботіоаміда (HL $\left.{ }^{4}\right)$ отримано кординаиійні сполуки загальної формули $\left[\mathrm{Cu}\left(\mathrm{HL}^{4}\right) \mathrm{Cl}_{2}\right]_{2} \cdot \mathrm{xCH}_{3} \mathrm{OH}(x=0,2)$. Молекулярна $i$ кристалічна структура комплексу $\left[\mathrm{Cu}\left(\mathrm{HL}^{4}\right) \mathrm{Cl}_{2}\right]_{2} \cdot 2 \mathrm{CH}_{3} \mathrm{OH}$ встановлена методом рентгеноструктурного аналізу.

Ключові слова: гетероциклічні тіоаміди, біядерні комплекси купруму(II), рентгеноструктурний аналіз. 